\title{
Impact of Changes in Land Use and Land Cover in the Contribution Basin of Doutor João Penido Water Supply Reservoir of Juiz de Fora, MG, Brazil
}

\author{
Juliana Nazareth de Lana ${ }^{1}$, Márcio de Oliveira ${ }^{2}$, Vanessa Romario de Paula ${ }^{1}$ \& Cézar Henrique Barra Rocha ${ }^{1,2}$ \\ ${ }^{1}$ Postgraduate Program in Constructed Environment, Federal University of Juiz de Fora, Juiz de Fora, Brazil \\ ${ }^{2}$ School of Engineering, Federal University of Juiz de Fora, Juiz de Fora, Brazil \\ Correspondence: Cézar Henrique Barra Rocha, School of Engineering, Federal University of Juiz de Fora, Juiz de \\ Fora, MG, 36036-330, Brazil. E-mail: barra.rocha@engenharia.ufjf.br
}

Received: February 12, $2021 \quad$ Accepted: March 14, $2021 \quad$ Online Published: March 21, 2021

doi:10.5539/jms.v11n1p108 URL: https://doi.org/10.5539/jms.v11n1p108

\begin{abstract}
Changes in the land use and land cover in areas adjacent to water reservoirs directly affect the quality of this water. This research presents a study on the water quality in the basin of one of the most important public water supply reservoirs in the city of Juiz de Fora, Minas Gerais. The main objective of this study was to analyze the behavior of limnological parameters and the correlation with land use and land cover in the contribution basin of the Doutor João Penido reservoir (CBJPR). The methodology was based on the analysis of water quality parameters, related to water samples collected from 2012 to 2015 . Six sampling points were chosen from different locations: spring, medium course, main tributaries of the reservoir and the reservoir catchment. The parameters analyzed were turbidity, total solids (TS), oxygen consumed (OC), dissolved oxygen (DO), electrical conductivity, total nitrogen (TN), total phosphorus (TP), E. Coli, temperature, $\mathrm{pH}$ and total dissolved solids (TDS). The Kendall's tau test was used to analyze the correlations between the parameters of water quality, land use and land cover in the CBJPR. In general, measured parameters showed better results in spring and in reservoir catchment, showing a worse quality of the water along the tributaries and the dilution power of the reservoir. The correlations pointed to the need for protection and preservation of forests in strategic locations to ensure good water quality.
\end{abstract}

Keywords: environmental monitoring, environmental impact, water resources

\section{Introduction}

The intensification of the demand for fresh water due to the increase in population, as well as the irregular distribution between housing and water resources, caused the need to store water in many parts of the planet (Straskraba \& Tundisi, 2013), especially in places close to urban areas. These transformations have a strong impact on ecosystems and drainage basins (López-Doval et al., 2017; Pickett et al., 2011).

As pointed out by Rebouças et al. (2006), reservoirs are created for a specific primary use, which has a funreservoirental influence on their morphology, morphometry and limnology. However, many reservoirs, after their primary use, come to have multiple uses, which leads to a more complex management mechanism.

The water quality of a body of water is impacted, directly or indirectly, by everything that occurs in the drainage area, especially when there is strong anthropogenic pressure in its surroundings (Nobre et al., 2020). The presence of untreated sewage and industrial effluents can cause biological and chemical contamination, affecting the health and life of aquatic species (Brasil, 2014). Erosion and dissipation of water from the surface increase turbidity and cause water pollution and siltation of the rivers (Pandey et al., 2016). The same occurs with the pesticides used in agriculture, which can be dragged and cause toxicological risks to aquatic fauna and to people who use that same water, downstream (Bernhardt, 1990; Carneiro \& Andreoli, 2005; Moschet et al., 2014; Palma et al., 2014).

Water quality is affected by the interaction between natural and anthropogenic factors on a series of temporal and spatial scales. Among these anthropogenic factors, changes in land cover, for example, can affect the quality of a watercourse, which makes quality control a challenge due to the complexity of the sources of impact (Nguyen et 
al., 2017). The type of land use and vegetation cover have a marked effect on the nutrient load added to the reservoir (Mello et al., 2018; Rodrigues et al., 2018; Straskraba \& Tundisi, 2013).

Studies point out three main aspects that lead to the deterioration of the quality of the water in the reservoirs, from the organic and inorganic elements conserved in the flooded area or introduced, during and after the flood (Carneiro \& Andreoli, 2005): (a) Transport of nutrients, especially phosphorus and nitrogen, from urbanized areas, by the release of sewage, and from agricultural areas, by the use of fertilizers; (b) Transport of sediments, such as sand, silt and clay, to the drainage basin, motivated by processes of erosion and decomposition of organic matter from plants and animals in the reservoir; (c) Introduction of toxic substances, such as pesticides and heavy metals, and pathogenic organisms through the atmosphere, sewers and rainfall.

Characterizing the relationship between land use and water quality increases the understanding of anthropogenic influences on aquatic conditions. This knowledge can help decision makers to improve policies related to land use in drainage basins, as well as improve practical strategies for the control of pollution caused by the land use. The limnological and ecological study of reservoirs consists of a fundamental databank for management and sustainable exploration for their multiple uses (Straskraba \& Tundisi, 2013). The water supply springs are environmental assets that need the attention of the society as a whole, and the monitoring of limnological variables offers indications regarding all natural and anthropogenic dynamics comprised in the drainage basin (Gu et al., 2019; Rocha et al., 2014; Tundisi, 2018).

Water resources have been in strong demand in large urban centers with high population density. The lack of sanitation, inefficient drainage systems and the reduction of vegetation around the body of water can, consequently, cause a considerable worsening in water quality (ANA, 2010; Oliver et al., 2019; Silva \& Poleto, 2017; Tasdighi et al., 2017). Machado (2012) states that in Juiz de Fora, where the rapid urban expansion occurs, in many cases, in the direction of the areas where the water springs for the public supply of the city are located, the issues concerning the misuse of water resources, lack of planning and inadequate management are very evident, which creates serious problems for the water springs used for public supply. Urbanization is a transformation trend that causes variabilities in the hydrological cycle and propagates changes in the water quality of water resources (Pickett et al., 2011). In this context, there is a need to analyze the procedures regarding land use and cover and their implications for the aquatic environment.

The present study was carried out in the Contribution Basin of the Dr. João Penido Reservoir (CBJPR), located in the city of Juiz de Fora (MG), in the southeastern region of Brazil. Due to the importance of the reservoir for the city of Juiz de Fora, the quality of its water was the subject of investigation by some authors (Rocha \& Branco, 1986; Pereira, 1991; Rocha et al., 2014; Bucci \& Oliveira, 2014; Bucci et al., 2015; Rocha \& Pereira, 2016; Rocha et al., 2020).

This article aims to analyze the correlation between water quality parameters and land use and land cover in the CBJPR, in the period between 2012 and 2015. The results presented can contribute to the field of environmental management, presenting the situation of the CBJPR, and also, it can be a basis of comparison for current and future works in the area.

\section{Method}

\subsection{Characterization of the Study Area}

The contribution basin of the Dr. João Penido reservoir is located in the north of the city of Juiz de Fora, state of Minas Gerais, southeastern Brazil. The climate of the region has two well-defined seasons, a rainy season, from October to April, with high temperatures and high average rainfall, and another, a dry season, from May to September, with less rain and colder (Juiz de Fora, 2004).

The Dr. João Penido reservoir was built through the damming of the Burros stream, also having the Grama stream and the Vista Alegre stream as important tributaries. The works ended in 1934, with the sole purpose of serving as a reservoir for the accumulation of water to supply the city of Juiz de Fora. Currently, it supplies about $50 \%$ of the city (CESAMA, 2019). Figure 1 presents a map showing the location of the city of Juiz de Fora and the CBJPR. 


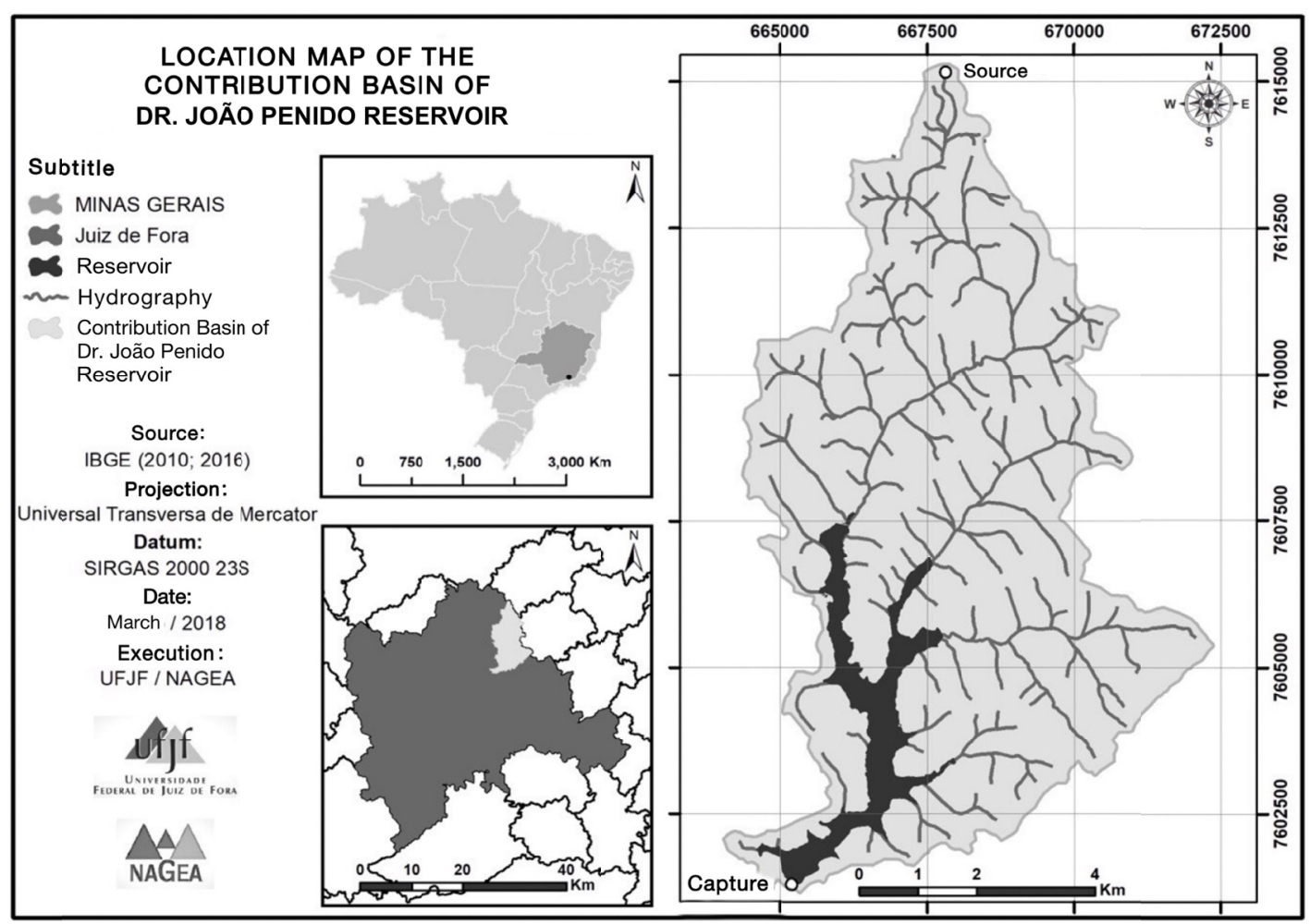

Figure 1. Location map of the contribution basin of the Dr. João Penido reservoir, Juiz de Fora - MG, authors' own study (adapted from Rocha et al., 2019a)

\subsection{Sampling Points}

The sampling points were chosen by the team from the Geo Environmental Analysis Center of the Federal University of Juiz de Fora-FUJF, in the period prior to May 2012, meeting the criteria established by the National Guide for Sample Collection and Preservation-CETESB (2011). The study was based on the locational criteria and on the use of the tool Google Earth to identify the area; on-site visits were also made to assess and identify differences in physiognomy, possible impacts on the waters and the contribution of tributaries to the Dr. João Penido reservoir. The geographical coordinates of the sampling points, in the horizontal Datum WGS-84, were obtained with the aid of a Garmin GPSmap 76CSx model GPS.

The point P1 represents the water with the minimum of anthropogenic interference since it is the spring of the Vargem Grande stream. Point P2, located in the medium course of the Burros stream, reflects the conditions of the water coming from the spring and subject to the effects of land use and cover in the sub-basin. Point P3 represents the mouth of the Burros stream in the reservoir, which is in a water passage under the Highway AMG-3085, opened in 2017 and located in Barreira do Triunfo. Point P4 is located next to a private property and is on the continuity of Highway AMG-3085, under a triple tubular culvert made of concrete, it is a very flat region, being the section that suffers the most with the changes resulting from the construction of the highway. The roads reduce connectivity and flow of materials (García-Montoya et al., 2016; Pocewicz \& Garcia, 2016; Brejão, 2012; Pringle, 2006), being occasionally sources of pollution. The operation and maintenance of the road facilitates the transport of sediments, debris and toxic elements (oils and greases), resulting in the worsening of water quality (Forsyth et al., 2006; Godwin et al., 2003). Point P5, like P4, is located in a very flat region within Enseada Condominium and its waters also have a low speed. Finally, the data related to point P6 represents the water that will be treated at the Water Treatment Plant Marechal Castelo Branco, in view of the proximity to the water catchment point of the Municipal Sanitation Company - CESAMA. Table 1 presents the sampling points in the CBJPR and Figure 2 illustrates the main tributaries, as well as the location of the points. 
Table 1. Sampling points in the CBJPR — Coordinates in the UTM system, datum SIRGAS2000, zone 23K (authors' own study)

\begin{tabular}{llll}
\hline Point & X & Y & Description \\
\hline P1 & 667601 & 7614960 & Spring of the Vargem Grande stream \\
P2 & 668961 & 7610333 & Medium course of the Burros stream \\
P3 & 665994 & 7607674 & Mouth of the Burros stream \\
P4 & 668896 & 7608454 & Grama stream \\
P5 & 668350 & 7605570 & Mouth of the Vista Alegre stream \\
P6 & 665212 & 7601233 & Water Catchment \\
\hline
\end{tabular}

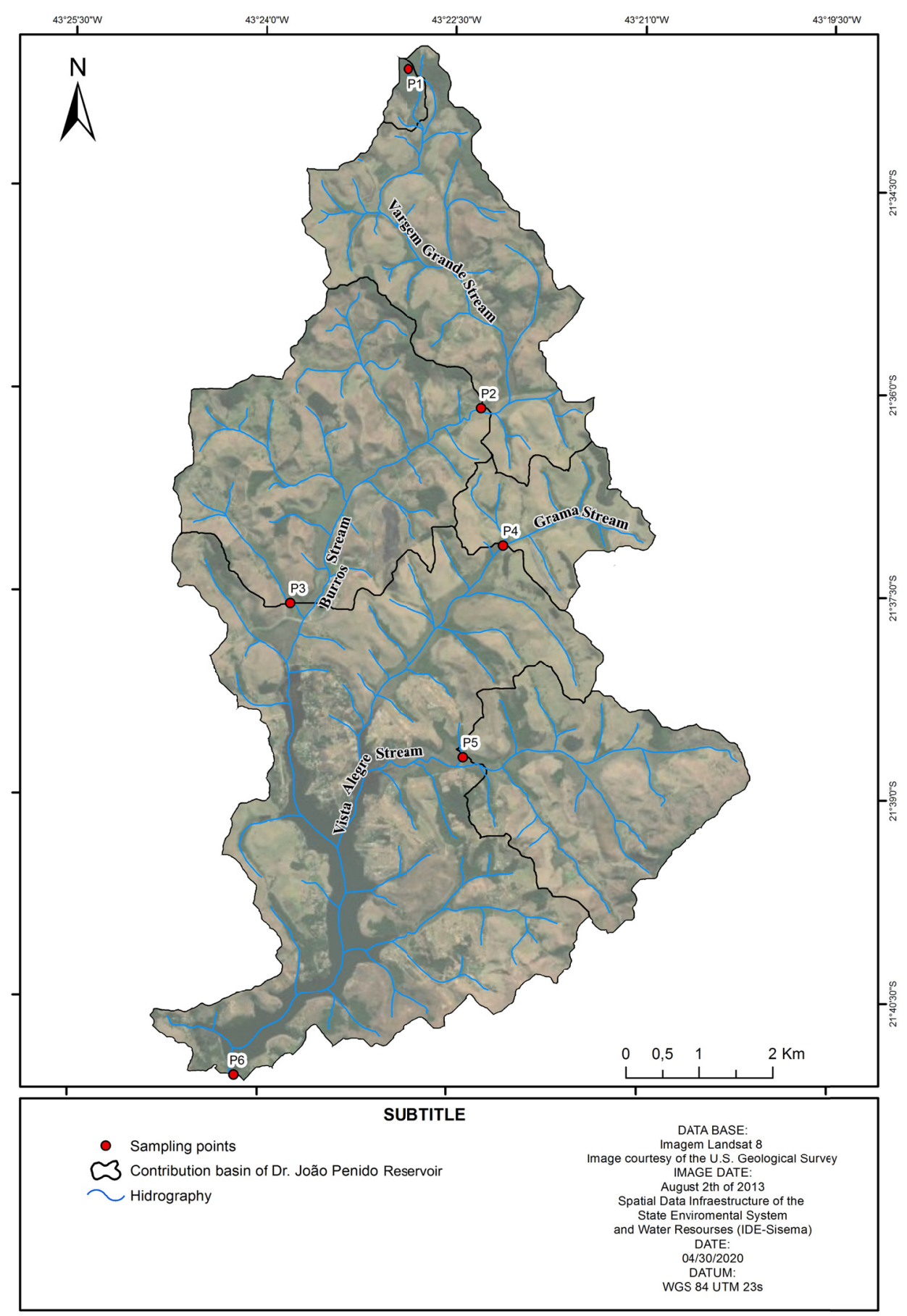

Figure 2. Main tributaries of the CBJPR and sampling points, Juiz de Fora - MG (authors' own study) 


\subsection{Data Concerning Water Quality}

The water quality data were provided by GEAC and refer to collections performed monthly between May 2012 and October 2014; in December 2014; in March 2015 and two collections in the month of April 2015, totaling 34 (thirty-four) collections. The time span concerning the analysis of water quality favors the understanding of the relationship with land use and avoids distortions caused by seasonal variations and occasional discharges that may occur (Mello et al., 2018). The samples were collected at 6 (six) sampling points distributed throughout the CBJPR. The field procedures were guided by the National Guide for Sample Collection and Preservation (CETESB, 2011). At each sampling point, 5 liters of water were collected for further analysis of the parameters. The analyzes were carried out at DLEA-Dynamic Laboratory of Environmental Analysis-and at LAE - Laboratory of Aquatic Ecology, both from FUJF. The laboratory procedures adopted followed those described in the APHA (2012). As for coliform analyzes, these were performed in a private laboratory.

The databank provided by GEAC is composed of 17 water quality parameters, namely: temperature, $\mathrm{pH}$, total solids, electrical conductivity, turbidity, silicate, dissolved oxygen, oxygen consumed, chemical oxygen demand, biochemical oxygen demand, nitrate, nitrite, ammonia, organic nitrogen, total nitrogen, total phosphorus and $\mathrm{E}$. Coli. From the data provided, the number of water quality parameters to be used in this study was reduced, these being listed in Table 2. The table also informs the number of observations $\left(\mathrm{N}^{\circ}\right.$ obs.) recorded for each water quality parameter, per sampling point, as not all collections present analysis of all parameters.

Table 2. Quality parameters of the water of the CBJPR - 2012 to 2015 (authors' own study)

\begin{tabular}{|c|c|c|c|c|c|c|c|}
\hline Parameter & Unit & $\begin{array}{l}\mathrm{N}^{\circ} \text { obs } \\
\mathrm{P} 1\end{array}$ & $\mathrm{~N}^{0}$ obs $\mathrm{P} 2$ & $\mathrm{~N}^{0}$ obs $\mathrm{P} 3$ & $\mathrm{~N}^{\mathrm{o}}$ obs $\mathrm{P} 4$ & $\begin{array}{l}\mathrm{N}^{\circ} \text { obs } \\
\mathrm{P} 5\end{array}$ & $\mathrm{~N}^{\circ}$ obs $\mathrm{P} 6$ \\
\hline Total solids (TS) & $\mathrm{mg} . \mathrm{L}^{-1}$ & 28 & 28 & 28 & 28 & 27 & 28 \\
\hline $\begin{array}{l}\text { Electrical conductivity } \\
\text { (Cond) }\end{array}$ & $\mu \mathrm{S} . \mathrm{cm}^{-1}$ & 31 & 32 & 30 & 31 & 32 & 31 \\
\hline Turbidity (Turb) & UNT & 32 & 32 & 32 & 32 & 32 & 32 \\
\hline OD & $\mathrm{mg} \cdot \mathrm{L}^{-1}$ & 32 & 32 & 28 & 24 & 30 & 30 \\
\hline $\mathrm{OC}$ & $\mathrm{mg} \cdot \mathrm{L}^{-1}$ & 28 & 28 & 28 & 28 & 28 & 26 \\
\hline Total nitrogen (TN) & $\mathrm{mg} \cdot \mathrm{L}^{-1}$ & 32 & 32 & 32 & 32 & 32 & 32 \\
\hline Total phosphorus (TP) & $\mathrm{mg} \cdot \mathrm{L}^{-1}$ & 31 & 32 & 32 & 31 & 32 & 32 \\
\hline E. Coli & NPM. $100 \mathrm{ml}^{-1}$ & 15 & 15 & 16 & 15 & 15 & 16 \\
\hline
\end{tabular}

Note. pH: potential of hydrogen; DO: dissolved oxygen; OC: oxygen consumed; COD: chemical oxygen demand; BOD: biochemical oxygen demand; E. Coli: Escherichia Coli

\subsection{Land Use and Land Cover in the CBJPR}

The data to analyze the associations between the percentages of the classes land use and land cover in the sub-basins of each sampling point and the results of the water quality parameters were derived from the map of land use and land cover of the CBJPR, for the year 2013.

The classes were defined from an observation of the landscape through images of the region studied, using the Google Earth Pro, other related works (Ribeiro, 2012; Casquin, 2016; Oliveira, 2018; Rocha et al., 2019a; Rocha et al., 2020) and the study of the land use and land cover manual published by the IBGE (2013). Several studies use the identification of the different uses of land located around the area of a reservoir to assess the impact on water quality (Clément et al., 2017; Mehdi et al., 2015; Nguyen et al., 2017). Table 3 presents the classes used in this research and their descriptions. 
Table 3. Classes of land use and land cover (authors' own study)

\begin{tabular}{|c|c|}
\hline Class & Description \\
\hline 1. Urbanized area & $\begin{array}{l}\text { "They comprise areas of intensive use, structured by buildings and road systems, where non-agricultural artificial } \\
\text { surfaces predominate." (IBGE, 2013). In addition to residences, infrastructure works were considered in this research } \\
\text { (paved roads and impermeable areas). }\end{array}$ \\
\hline 2. Pasture & $\begin{array}{l}\text { In the CBJPR, the soil covered with grassy vegetation was included in this class. In general, it is used for pasture, and, } \\
\text { according to IBGE (2013), this class corresponds to "the area for cattle grazing, formed by planting perennial forages } \\
\text { or using and improving natural pastures. In these areas, the soil is covered by grasses and/or leguminous vegetation, } \\
\text { the height of which can vary from a few decimeters to a few meters". }\end{array}$ \\
\hline 3. Exposed land & $\begin{array}{l}\text { The areas of exposed land are characterized by not presenting any type of cover, that is, they are bare (Ribeiro, 2012). } \\
\text { The areas without vegetation cover or building and those that are not flooded were considered in this class. In the } \\
\text { CBJPR, an unpaved road was also considered as exposed land. }\end{array}$ \\
\hline 4. Dirty pasture & $\begin{array}{l}\text { The areas of the class dirty pasture correspond to those that are in a state of regeneration and are occupied by } \\
\text { herbaceous and shrubby species, probably due to the abandonment of the pasture area (Ribeiro, 2012). It is an } \\
\text { intermediate class between pasture and arboreal vegetation. They are located both in the high regions of the local } \\
\text { relief as well as in the low areas subject to flooding. }\end{array}$ \\
\hline $\begin{array}{l}\text { 5. Arboreal } \\
\text { vegetation }\end{array}$ & $\begin{array}{l}\text { The class "areas of natural vegetation", proposed by the IBGE (2013), comprises a "set of forest and field structures, } \\
\text { ranging from original (primary) and altered forests and fields to secondary spontaneous forest, shrubby, herbaceous } \\
\text { and/or grassy-woody formations, in different successional stages of development, distributed across different } \\
\text { environments and geographical situations." In the studied area, it was considered as a remnant of the Atlantic Forest. } \\
\text { Through the image, it was not possible to separate the different successional stages, nor the phytosociological } \\
\text { variations. Therefore, in this class, eucalyptus plantations were also considered. }\end{array}$ \\
\hline 6. Wetland & $\begin{array}{l}\text { This class corresponds to "areas that are generally close to water reservoirs and the natural courses of the rivers or } \\
\text { following the drainage network. They are usually located in the lower parts" (Ribeiro, 2012). In the CBJPR, they are } \\
\text { the wetland regions of the watercourses. It is associated with the presence of bodies of water. }\end{array}$ \\
\hline 7. Reservoir & $\begin{array}{l}\text { With regard to the class "waters" proposed by the IBGE (2013), these include "all classes of inland and coastal } \\
\text { waters, such as watercourses and channels, naturally closed bodies of water, with no movement, and artificial } \\
\text { reservoirs, in addition to coastal lagoons or ponds, estuaries and bays." In the case of the studied area, there is the Dr. } \\
\text { João Penido reservoir. }\end{array}$ \\
\hline
\end{tabular}

For the elaboration of the land use and land cover map, an image of the region studied was obtained from the Landsat 8 satellite, on $02 / 02 / 2013$, this date being chosen because it is within the period of collection of water samples. Through the Impact toolbox program, an automatic classification was performed, grouping into classes objects that present similarity in their spectral responses. This tool offers a pixel-based classification product to be used in processing steps, such as segmentation and mapping of land cover, resulting in a thematic map, in which each group of pixels of the original image was classified into one of the classes previously defined. Then, a review of the automatic classification by groups of pixels was carried out, manually, through the observation of a georeferenced image from Google Earth taken on the same date, in order to correct any errors. For this purpose, the ESRI ArcGIS 10.3 software was used.

\subsection{Statistical Analysis of the Data}

Regarding the CBJPR, in order to reduce the number of water quality parameters to be analyzed, a cluster analysis was carried out. The grouping of the variables was based on a degree of similarity, sufficient to bring them together in the same set. Thus, based on the results of this study, the analysis of the water quality of the CBJPR can become simpler and have a lower cost. From the dendrogram, the parameters that best represented certain groups of variables were selected. This analysis, with the respective graphical result, was performed in the R software. This technique was also used by Sabino et al. (2017) and by Oliveira (2018) to select water quality parameters to be used in their research, from a larger set of data. Bufon and Landim (2007) used this technique to group the same water quality parameters in the dry season and in the rainy season to analyze whether there was a different behavior between seasons.

To investigate whether there is a relationship between land use and land cover and water quality, an analysis was made regarding the percentages of land use and land cover in each sub-basin of the 6 sampling points, which was related to the data of the water quality parameters selected at each sampling point. The water quality parameters presented in Table 2 did not show a normal distribution, requiring the application of a non-parametric correlation test. Kendall's tau test was used. This same test was also used by Jia et al. (2018) to correlate groundwater pollution rates with land use.

In addition to Kendall's tau, p-values (with a significance level of 5\%) were calculated for each combination of 
land use and land cover and water quality parameters, using the R software. Rocha et al. (2020) used a method similar to this, in which they calculated the Spearman's " $\rho$ " to analyze the dynamics of limnological parameters and land use and cover. This method is also similar to Pearson's "R", used by Vanzela et al. (2010) and Buck et al. (2004) to correlate land use with surface water quality.

\section{Results and Discussion}

\subsection{Land Use and Cover in the CBJPR}

The classes of use and cover of the land encompassed in the CBJPR, in 2013, are shown in Figure 3. The contribution basin has a total area of $59.482 \mathrm{~km}^{2}$. The area occupied by class and the percentage that each represents in the total area of the CBJPR are shown in Table 4.

The map shows the classes of land use and land cover, the delimitation of the contribution basin, the location of the sampling points in the basin and the sub-basins of each point. The delimitation of the contribution basin was obtained through the databank provided by the City Hall of Juiz de Fora (aerophotogrammetric flight performed in June 2007). The sub-basins of each sampling point were generated using the ESRI ArcGIS 10.3 software, with the use of the Hydrology tool, from the level curves of the Light Detection And Ranging (LIDAR) of the City Hall of Juiz de Fora. The hydrographic network was obtained from the Spatial Data Infrastructure of the State System of Environment and Water Resources (SDI-Sisema). 


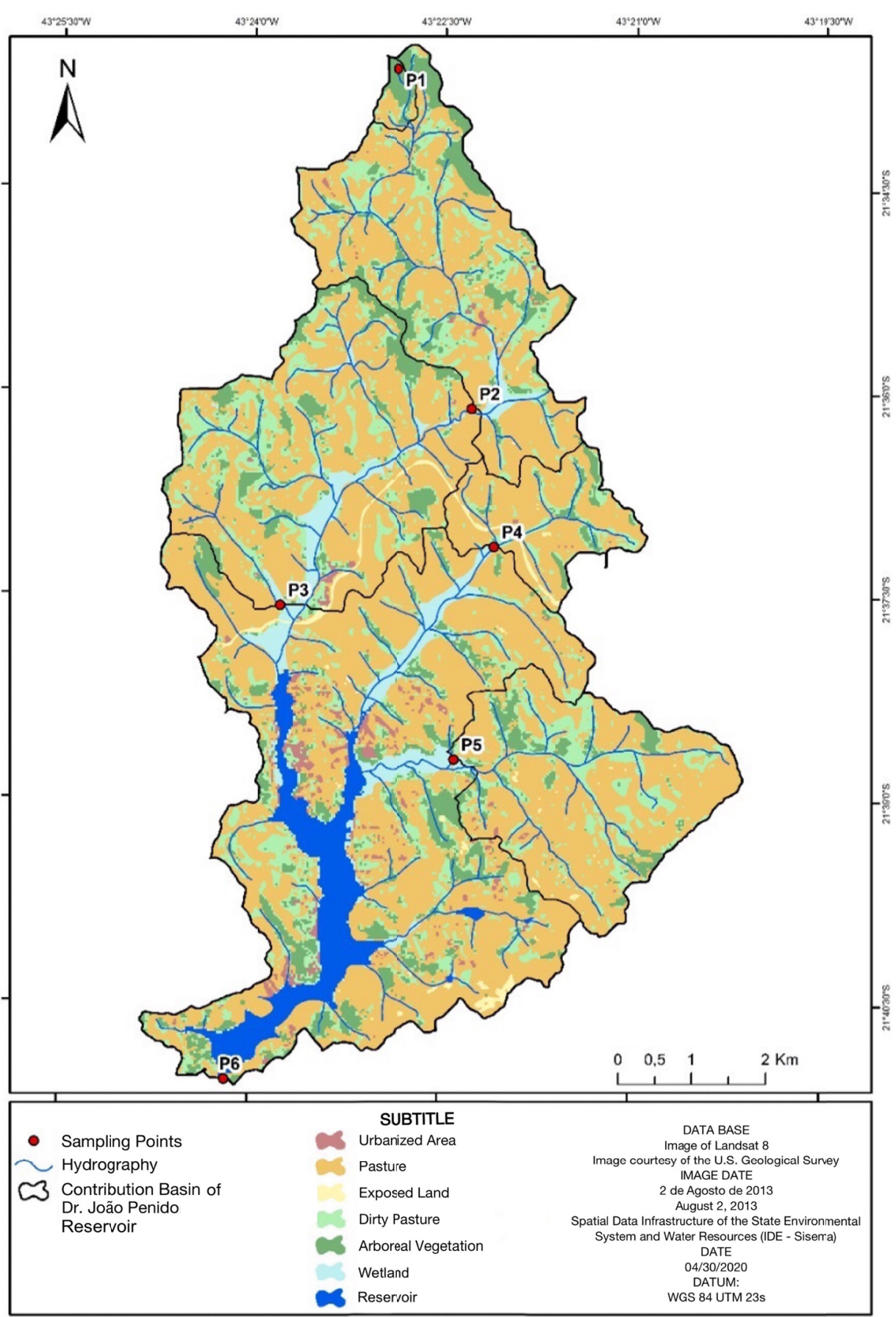

Figure 3. Map of land use and land cover of the CBJPR - 2013 (authors' own study)

Table 4. Classes of land use and land cover in the CBJPR - absolute area and percentage area - 2013 (authors' own study)

\begin{tabular}{lll}
\hline Class & Area $\left(\mathrm{km}^{2}\right)$ & Area $(\%)$ \\
\hline TOTAL & 59.482 & 100.00 \\
\hline Pasture & 36.089 & 60.672 \\
Dirty pasture & 10.638 & 17.884 \\
Arboreal vegetation & 6.296 & 10.585 \\
Reservoir & 2.671 & 4.490 \\
Wetland & 2.316 & 3.894 \\
Urbanized area & 0.977 & 1.643 \\
Exposed land & 0.495 & 0.832 \\
\hline
\end{tabular}


Table 5 shows the percentage that each class of land use and land cover occupies in the total area of each sub-basin of the sampling points. In order to carry out statistical analyzes of the correlation of water quality with land use and land cover, a section of the area of the sub-basins of points P2, P3 and P6 was considered, excluding the sub-basins located upstream of the point, as shown in Figure 3.

Table 5. Area, as a percentage, of each class of land use and land cover in the sub-basins of each sampling point (authors' own study)

\begin{tabular}{|c|c|c|c|c|c|c|}
\hline \multirow[t]{3}{*}{ Class } & Sub-basin P1 & Sub-basin P2 & Sub-basin P3 & Sub-basin P4 & Sub-basin P5 & Sub-basin P6 \\
\hline & Area & Area & Area & Area & Area & Area \\
\hline & $\%$ & $\%$ & $\%$ & $\%$ & $\%$ & $\%$ \\
\hline Pasture & 32.741 & 62.036 & 61.288 & 72.352 & 68.110 & 56.438 \\
\hline Dirty pasture & 15.228 & 23.427 & 21.144 & 15.750 & 22.324 & 13.079 \\
\hline Arboreal vegetation & 51.777 & 13.493 & 10.503 & 8.232 & 8.526 & 9.827 \\
\hline Reservoir & 0.000 & 0.000 & 0.000 & 0.000 & 0.000 & 10.450 \\
\hline Wetland & 0.000 & 0.256 & 5.535 & 0.155 & 0.269 & 6.181 \\
\hline Urbanized area & 0.254 & 0.707 & 0.575 & 0.217 & 0.355 & 3.129 \\
\hline Exposed land & 0.000 & 0.082 & 0.955 & 3.293 & 0.416 & 0.896 \\
\hline
\end{tabular}

Analyzing the map in Figure 3 and Tables 4 and 5, it is possible to verify that the basin is occupied, for the most part, by pasture areas and that most of the urbanized area is in the sub-basin of point P6, especially on the banks of the reservoir, occupying, in some cases, riverside areas, a situation also observed by Rocha et al. (2019b). The riverside area is the interface between terrestrial and aquatic ecosystems, playing an important role in the transfer of nutrients and sediments (Kuglerová et al., 2014). The riparian forest can contribute to the protection of water quality, however, it is one of the most degraded ecosystems in the world (Kuglerová et al., 2014; Nilsson \& Berggren, 2000). It is also observed that the sub-basin at point P1 is the one with the highest proportion of arboreal vegetation.

\subsection{Selection of Water Quality Parameters}

From the group of data provided by GEAC, a cluster analysis was carried out in order to select the parameters used in this study, and make an association between these and the classes of land use and land cover in the studied basin. Cluster analysis is an agglomerative hierarchical multivariate technique, the result of which presents maximum homogeneity of objects within groups and, at the same time, maximum heterogeneity between groups (Rong, 2011). By reducing the number of variables to be monitored and analyzed, the costs related to field activities and analysis of collected samples can also be reduced.

Regarding the choice of parameters, those that could prove the hypothesis of this research were chosen, that is, that the land use and land cover in the CBJPR can degrade water quality. Figure 4 presents the identified groups. The response variables that were selected are those presented in Table 2, namely: TS, Cond, Turb, DO, OC, TN, TP and E. Coli. 


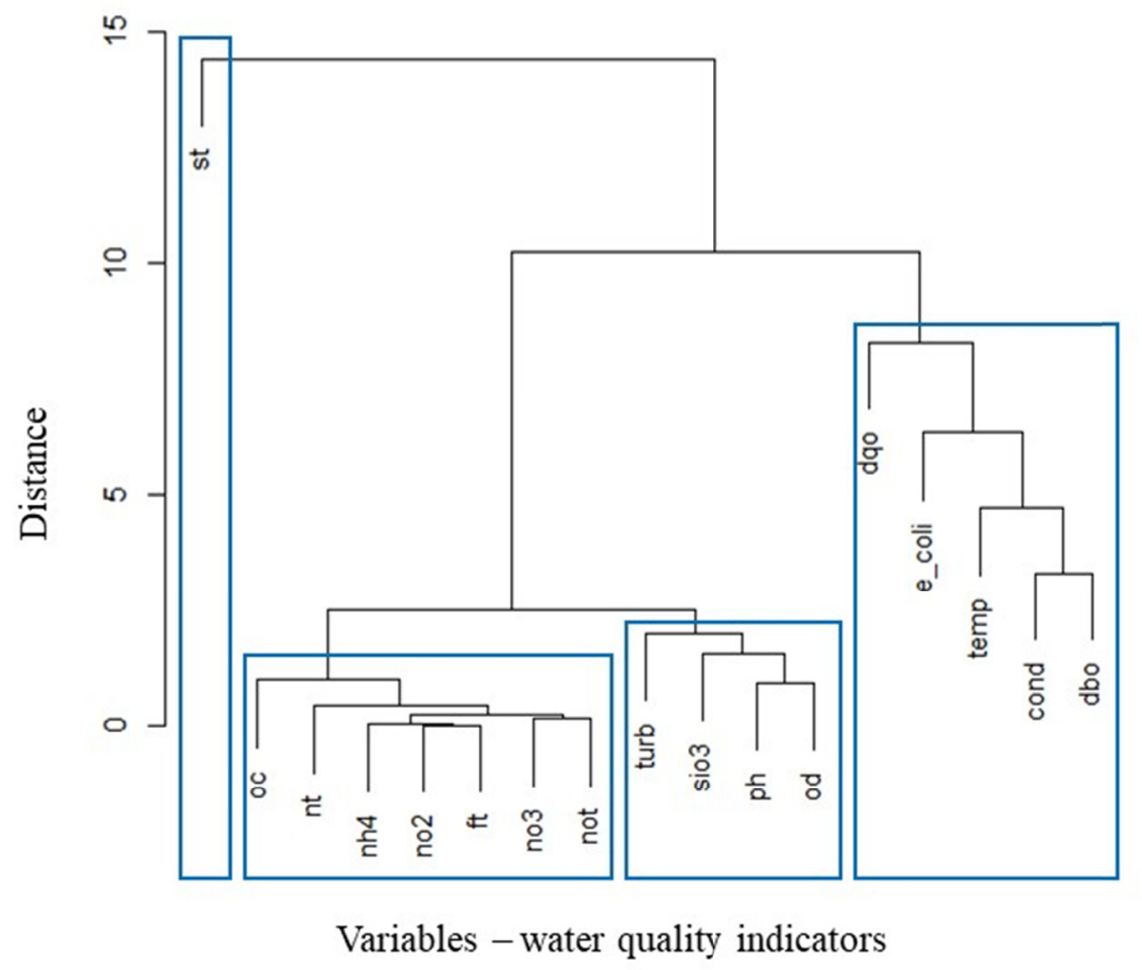

Figure 4. Cluster analysis of water quality variables - dendrogram (authors' own study)

Note. TS: total solids; OC: oxygen consumed; TN: total nitrogen; NH4: ammonia; NO2: nitrite; TP: total phosphorus; NO3: nitrate; Norgt: organic nitrogen; turb: turbidity; $\mathrm{SiO}$ : silicate; $\mathrm{Ph}$ : potential of hydrogen; DO: dissolved oxygen; COD: chemical oxygen demand; E. Coli: Escherichia Coli; temp: temperature; cond: electrical conductivity; BOD: biochemical oxygen demand.

In the dendrogram (Figure 4), from left to right, the first group is formed only by the parameter TS. This represents the presence of solids in the water, whether they are suspended, dissolved or colloidal. The impacts related to human action can intensify the erosive processes in the drainage basin, carry solids into the bodies of water and lead to the discharge of effluents into the bodies of water (Tasdighi et al., 2017). In the case of the CBJPR, the works on the Highway AMG-3085 that involve soil movement and the discharge of effluents without previous treatment may cause changes in this parameter in the water. According to Mello et al. (2018), most Brazilian rivers have a high incidence of organic waste, fecal coliforms, phosphorus and nitrogen, due to the lack of sanitation.

The second group contains the parameters OC, TN, NH4, NO2, NO3, TP and Norg. This group represents indicators of organic load and nutrients present in the water. Within the group, considering the availability of the readings, the parameters $\mathrm{OC}, \mathrm{TN}$ and TP were chosen. The parameter OC was chosen because it is considered an effective indicator of the presence of organic matter, as it indicates the oxygen consumed in its degradation. According to Valente et al. (1997), the term "oxygen consumed" chemically has the same meaning as the chemical demand for oxygen, which is an indicator of organic matter based on the concentration of oxygen required to oxidize organic matter. On the other hand, the choice of TN and TP was due to the fact that they represent important nutrients for the growth of algae and aquatic plants, which, in high concentrations, can degrade the multiple uses of these waters, compromising the quality of the water for public supply or causing eutrophication and death of aquatic organisms (Santos et al., 2017; Shi et al., 2017; Wang \& Yin, 1997; CETESB, 2016). In the case of the CBJPR, they can be associated with domestic sewage dumps and fertilizers used in the soil, which can be carried into the bodies of water. In the case of the supply reservoirs, another consequence of the presence of nutrients is the increase in water treatment costs, due to the toxicity of many algae, the removal of the algae itself and the removal of color, taste and odor.

The third group is formed by the parameters turbidity, $\mathrm{SiO} 3, \mathrm{pH}$ and $\mathrm{DO}$. These variables may be related to the presence of organic matter in the water and material carried into the watercourses from soil erosion. From this group, the turbidity variable was chosen, since changes in the degree of turbidity require operational maneuvers 
at Water Treatment Plants, such as changes in the dosages of coagulants and auxiliaries, and the treatment of turbid waters for human consumption is expensive (CETESB, 2016). The parameter DO was chosen because it is an important parameter with regard to water quality and fundamental for maintaining the dynamics of aquatic ecosystems, furthermore, it shows the balance between the processes that produce and consume oxygen in the body of water (Ahmed, 2017), being one of the main ones regarding the monitoring of water quality (Kisi et al., 2020). An adequate supply of DO is essential for the maintenance of self-depuration processes in natural aquatic systems (CETESB, 2016). According to Rocha et al. (2019a), DO is a fundamental parameter for aquatic life, and an environment with low dissolved oxygen can be considered polluted. In the case of the CBJPR, the factors that can reduce the concentration of DO are the presence of organic matter and nutrients.

In the fourth group are the parameters COD, E. Coli, temperature, Cond and BOD. This group represents indicators of organic matter, from sewage discharge without prior treatment. The parameter E. Coli was chosen because it is a bacterium that does not reproduce in water or in the soil, but exclusively inside the intestines of homeothermic animals (CETESB, 2016). The detection of E. Coli in the body of water is indicative of contamination by fecal waste, and is used by several countries to monitor water quality (WHO, 2016). Electrical conductivity was chosen because, according to Oliveira (2018), it shows the change in the quality of a body of water, so, in the case of the CBJPR, it can be a good indicator of pollution at specific points or at the same point over time. Electrical conductivity correlates to numerous water quality variables. Wang and Yin (1997) found 60 variables that were significantly correlated to it. It should be noted that the parameter COD was not chosen, since DO was chosen in the second group, and it has a behavior similar to that. Finally, although BOD is an indirect indicator of the amount of organic matter present in the water, being important for the control of water and sewage treatment plants, this parameter was not chosen due to the fact that there are some outliers in the database, in addition to some months in which this parameter was not included, which could compromise the analyzes and correlations made in this study.

\subsection{Kendall's Tau Correlating Land Use and Land Cover in the CBJPR with Monitored Water Quality Parameters}

In order to statistically analyze how the association between land use and land cover and water quality occurs, this section of the paper presents a discussion regarding tau values, the result of the Kendall's tau nonparametric test, which correlated the data regarding the water quality parameters presented in Table 2 with the percentages of land use and land cover classes in the CBJPR, presented in Table 5. The p-values (with a significance level of $5 \%$ ) were also calculated for each combination of land use and land cover and water quality parameters. Table 6 shows the Kendall's tau values. The values marked with * indicate a p-value less than 0.05 (with a significance level of 5\%), which were then analyzed.

Table 6. Kendall's tau correlating water quality parameters with land use and land cover in the CBJPR (authors' own study)

\begin{tabular}{|c|c|c|c|c|c|c|c|}
\hline & Pasture & $\begin{array}{l}\text { Dirty } \\
\text { pasture }\end{array}$ & $\begin{array}{l}\text { Arboreal } \\
\text { vegetation }\end{array}$ & Reservoir & Floodplain & Urbanized area & $\begin{array}{l}\text { Exposed } \\
\text { land }\end{array}$ \\
\hline Turbidity & $0.38^{*}$ & $0.22 *$ & $-0.32 *$ & 0.07 & $0.22 *$ & 0.13 & $0.32 *$ \\
\hline TS & $0.19 *$ & 0.04 & $-0.19^{*}$ & 0.02 & 0.06 & -0.07 & $0.19 *$ \\
\hline OC & $0.23 *$ & 0.14 & $-0.19 *$ & 0.06 & 0.14 & 0.06 & $0.21 *$ \\
\hline DO & $-0.33 *$ & $-0.21 *$ & $0.31 *$ & 0.11 & -0.05 & $0.27 *$ & $-0.27^{*}$ \\
\hline $\mathbf{T N}$ & $0.32 *$ & $0.29 *$ & $-0.17 *$ & -0.09 & 0.04 & -0.02 & $0.21 *$ \\
\hline $\mathbf{T P}$ & $0.23^{*}$ & 0.06 & $-0.18^{*}$ & -0.01 & 0.01 & -0.04 & 0.26 \\
\hline Cond. & -0.07 & -0.10 & 0.02 & 0.04 & -0.01 & -0.07 & 0.03 \\
\hline E. Coli & $0.42 *$ & $0.33^{*}$ & $-0.22 *$ & $-0.14 *$ & 0.03 & -0.01 & 0.20 \\
\hline
\end{tabular}

Note. TS: total solids; OC: oxygen consumed; DO: dissolved oxygen; TN: total nitrogen; TP: total phosphorus; Cond.: electrical conductivity; E. Coli: Escherichia Coli.

The class "pasture" showed expected correlations with water quality parameters. The positive correlation with $\mathrm{OC}(\mathrm{tau}=0.23)$ may indicate the consequence of livestock activities in the transport of organic matter to bodies of water, which is evidenced by the negative correlation with DO (tau $=-0.33)$. Vanzela et al. (2010) also found a positive correlation between $\mathrm{DO}$ and pasture. The positive correlation with the nutrients $\mathrm{TN}(\operatorname{tau}=0.32)$ and $\mathrm{TP}$ $(\operatorname{tau}=0.23)$ can also point to the effect of the transport of nutrients from these activities to bodies of water (Rocha et al., 2019a). Similar results with the nutrients TN and TP were observed by Buck et al. (2004). These results are in line with what Oliveira (2018) points out, namely that the impact of the class pasture on water 
quality is related to the transport of nutrients, especially TN and TP, which result from the use of fertilizers used to enrich the pasture. E. Coli is related to the excrement of animals, thus presenting a positive correlation (tau = $0.42)$. Finally, the positive correlation with turbidity $(\operatorname{tau}=0.38)$ and TS $(\operatorname{tau}=0.19)$ shows that there is a transport of material to the bodies of water. When there is less soil coverage and less protection against the erosive action of rain, the generation of material to be eroded and transported to the watercourse bed is more likely.

The correlations between the class "dirty pasture" and the parameters DO (tau $=-0.21), \mathrm{TN}(\operatorname{tau}=0.29)$, E. Coli $(\operatorname{tau}=0.33)$ and turbidity $(\mathrm{tau}=0.22)$ presented tau values similar to those of the correlation of these parameters with the class "pasture", however, with lower values. The class "dirty pasture" was considered in this research as representing those areas that are in a state of regeneration, probably due to the abandonment of the pasture area.

The class "arboreal vegetation" showed negative correlations with the parameters TS (tau $=-0.19)$ and turbidity $(\operatorname{tau}=-0.32)$, which can be explained by the ability of vegetation to prevent water dissipation from the surface, therefore making it difficult to carry materials. According to Nunes et al. (2019), the forest is extremely important for the maintenance of the integrity of a drainage sub-basin, due to its diverse functions, such as, for example, the filter function, filtering all the water coming from the adjacent areas that drain into the waterways. With this "filter", many sediments, toxic products and nutrients are retained, mainly TP and TN, which, in excess, cause the water eutrophication process. This statement may explain the negative correlations with TN (tau = $-0.17)$ and TP (tau $=-0.18)$. The class "arboreal vegetation" also showed a negative correlation with E. Coli (tau $=-0.22$ ), which shows less human presence and animal husbandry. The same class showed a positive correlation with the parameter DO $(\operatorname{tau}=0.31)$ and a negative one with the OC $(\operatorname{tau}=-0.19)$. These correlations point to the importance of preserving and protecting vegetation in strategic areas, such as riverside areas, for the availability and quality of the water of springs. Similar results were found by Casquin (2016) and Rocha et al. (2020). Rocha et al. (2019b) point out that, of the entire permanent preservation area (PPA) of the water bodies of the CBJPR, only $17 \%$ is occupied by forest and, with regard to the PPA of the reservoir banks, this number is only $15 \%$. If the rest of the APP were reforested, in the long term there could be a significant improvement in the availability and quality of water. According to Vanzela et al. (2010), the areas occupied by forests favor the increase of the specific flow due to the greater coverage, promoting the stability and infiltration of water in the soil, as they provide a reduction in the intensity of the dissipation of water from the surface. The conservation of the forest in the springs is an important factor in terms of preventing the degradation of water quality in streams. The preservation of riparian forests is necessary to protect the streams and conserve water quality. The restoration of the riparian forests, by increasing forest cover and decreasing agriculture and pastures, can decrease the loads of sediment, nitrogen and phosphorus in the drainage basin (Mello et al., 2018; Taniwaki et al., 2017).

Analyzing the tau values for the correlations between water quality parameters and the classes "pasture", "dirty pasture" and "arboreal vegetation", it can be observed that the values for the class "dirty pasture" are between the values for the classes "pasture" and "arboreal vegetation" regarding the parameters DO, E. Coli, turbidity, TN and TP. These values are consistent with the description of the classes, since "dirty pasture" can be considered an intermediate class between "pasture" and "arboreal vegetation". If the areas of "dirty pasture" remain abandoned, they tend to become an area of "arboreal vegetation" at an early stage of succession.

The class "reservoir" showed a negative correlation with the E. Coli (tau $=-0.14)$ and the class "Floodplain" showed a positive correlation with turbidity $($ tau $=0.22)$. This class corresponds to the vegetation of the flooded areas, rich in mineral and organic sediments, which may explain this association.

The class "urbanized area" showed a positive correlation with DO $(\operatorname{tau}=0.27)$. This result is contradictory from the environmental point of view. The following facts may explain this positive correlation: the highest values of DO were at point P6, the point of water collection by the Cesama, in which there is a greater volume of water and, consequently, a greater dilution. The sub-basin at this point is the one with the highest percentage of the class "urbanized area" (3.129\%) and, through the land use and occupation map, it can be seen that the anthropogenic occupation is greater on the banks of the reservoir. This correlation was also presented by Rocha et al. (2020), which claim that this result needs to be further investigated. As a limitation of the statistical method used, there is the fact that the classes of land use and land cover are not independent (as they were considered), that is, an increase in the percentage of the class "urbanized area" causes a decrease in the other classes.

The correlations with the class "exposed land" presented the expected results. The positive correlation with turbidity $(\operatorname{tau}=0.32)$ indicates that material is carried into the bodies of water, which is corroborated by the other correlations, namely those positive with the $\mathrm{OC}(\operatorname{tau}=0.21)$ and with the nutrient $\mathrm{TN}(\operatorname{tau}=0.21)$ and negative with the DO (tau $=-0.27)$. The areas of exposed land are those considered in this research as bare. According to 
Peña-Arancibia et al. (2019), the deforestation of areas with vegetation, especially the riparian areas, as well as the incorrect use of the soil, reduce the infiltration rate, increase the dissipation of water from the surface and may cause the reduction of groundwater recharge. As a consequence of the removal of the vegetal covering from the spring areas, there is an increase in the volume and speed of the dissipation of water and erosion, which directly affects the quality and hydrodynamics of the bodies of water.

It is interesting to mention a study carried out in Juiz de Fora, in which part of the databank regarding water quality parameters used in that study is the same used in this research. Rocha et al. (2020) correlated the limnological parameters of the main tributaries of the Dr. João Penido and São Pedro reservoirs, also located in the city of Juiz de Fora, with land use in the drainage basins of these springs, using Spearman's " $\rho$ " correlation coefficient. Water samples were collected monthly between May 2012 and December 2013, at 6 points in the CBJPR and at 4 points in the contribution basin of the São Pedro reservoir, totaling 10 sampling points. Regarding the results, they demonstrated that the class Forest brought a significant increase in DO and a significant decrease in TN, TP and TS. The pasture caused a significant increase in coliforms, TS and TP, being possible to notice, on the other hand, a decrease in DO, corroborating the results found by Rocha et al. (2019a) in work carried out in that same area. The class Urbanization caused a significant increase in DO, coliforms, turbidity, conductivity and a significant decrease in TN. The results presented are similar to those of this research. They also point out, in relation to the Highway AMG-3085, that it may boost the densification of urban expansion, which is not desirable regarding water quality. The protection of native vegetation in the areas adjacent to the springs is essential for the management of the drainage basins and for the maintenance of water quality (Mello et al., 2018).

Literature has been linking water quality with land use and the state of conservation of the vegetation cover in the drainage basins, reporting that the higher the level of preservation in the basin, the better the quality of its water (Rabelo et al., 2009; Menezes et al., 2014; Kändler et al., 2017; White et al., 2013).

\subsection{Discussions and Recommendations}

In a current study conducted in the CBJPR and developed between the years 2019 and 2020, Lana (2020) performed readings of water quality parameters with a multiparametric probe at the same six sampling points and observed that some qualitative parameters of water show significant differences by sampling point and by season, namely dry and rainy. Among the parameters analyzed by Lana (2020) are DO and Cond., which are parameters in common with those of this research. At points $\mathrm{P} 1$, spring, where there is a fragment of forest that is better preserved, and $\mathrm{P} 6$, catchment of the reservoir, readings indicate better water quality. At intermediate points (P2, P3, P4, P5), readings indicate a drop in water quality, with point P4 showing the worst results. This behavior is similar to that observed with regard to data for the years 2012 to 2015. As pointed out by Lana (2020), point P1 (spring) presents the lowest level of anthropogenic interference, and point P6 (catchment) presents a greater dilution capacity and can be characterized as a recovery zone.

However, it is necessary to continue monitoring the water quality of the CBJPR, so that the impacts caused by anthropogenic interference addressed in this research can be monitored and evaluated. This monitoring is a fundamental tool, providing assistance in decision-making to prevent problems resulting from the deterioration of water quality from causing damage to the normal use of the spring, making it impossible or significantly more expensive its use for public supply.

There are municipal laws that regulate the use of the basin to protect the reservoir. However, there is the occurrence of anthropogenic occupations on the banks of the reservoir, which demands the need for greater inspection regarding land use and land cover in the CBJPR. Protection of riverside areas is recommended, with the recovery of those areas through riparian vegetation. Riparian vegetation is essential for the protection of watercourses.

Regarding the sampling points P2, P3, P4 and P5, there are culverts that break the connectivity of the hydrological network and impair the flow of matter, energy and organisms, which promotes the proliferation of aquatic macrophytes. Their roots hinder the flow of water and the lack of maintenance is reflected in the siltation of the watercourses and the water reservoirs, which ultimately reduces their storage capacity. Attention is recommended to these places in order to perform continuous maintenance to avoid the accumulation of materials and the proliferation of macrophytes.

Regarding the land use and land cover in the CBJPR, it is worth mentioning the installation of the Highway AMG-3085, which, when crossing the contribution basin, poses risks to the reservoir. Traffic accidents can release substances that will cause water pollution. Regular use of the highway itself generates an environmental impact due to emissions from vehicles. The road was released for use in 2017, which induces anthropogenic 
occupation in its adjacent areas. Thus, a control action and good management of the basin are necessary, aiming to preserve the water quality of the reservoir for public supply. The control action is important both to avoid the growth of occupations in the area of the basin, such as the urbanized area and pasture, and to ensure that there are requirements for sewage treatment, in view of the fact that untreated domestic effluents are discharged into the bodies of water.

\section{Conclusion}

This study aimed to analyze the associations between water quality parameters and land use and land cover in the CBJPR, between 2012 and 2015. The correlations between the percentages of the classes of land use and land cover and the results of water quality parameters pointed to the need to protect and preserve the arboreal vegetation, highlighting its importance for the quality and quantity of water in the springs. Changing the data series or choosing another correlation variable can change the associations that were observed, considering that other factors, in addition to land use and land cover, influence water quality, such as, for example, morphology, geology and soils, which were not taken into account in this research.

Among the limitations identified during the research, it can be highlighted that, in order to obtain more significant conclusions and more reliable results regarding the association between the variables analyzed using the Kendall tau test, it is pertinent to have increasingly frequent periods of monitoring of water quality and land use and land cover.

In general, it is evident, from the content presented, that the contribution basin of the Dr. João Penido reservoir requires urgent measures for the environmental management of the area, in order to preserve the water of the reservoir, which is used for public supply.

\section{Acknowledgments}

The authors would like to thank the Postgraduate Program in Constructed Environment (PROAC) of the Federal University of Juiz de Fora (UFJF) and to the Geo Environmental Analysis Center (NAGEA).

\section{References}

Ahmed, A. A. M. (2017). Prediction of dissolved oxygen in Surma River by biochemical oxygen demand and chemical oxygen demand using the artificial neural networks (ANNs). Journal of King Saud University Engineering Sciences, 29(2), 151-158. https://doi.org/10.1016/j.jksues.2014.05.001

ANA. (2010). Atlas Brasil: Abastecimiento Urbano de Água. Ana, 1, 1-72.

APHA-American Public Health Association. (2012). Standard Methods for the Examination of Water and Wastewater (22nd ed.). Washington, DC: APHA.

Bernhardt, H. (1990). Control of reservoir water quality. In H. H. Hahn \& R. Klute (Eds.), Chemical Water and Wastewater Treatment. Berlim: Springer. https://doi.org/10.1007/978-3-642-76093-8_19

Brasil. (2014). Manual de controle da qualidade da água para técnicos que trabalham em ETAS. In Fundação Nacional de Saúde- FUNASA (1st ed., p. 112). Retrieved from http://www.funasa.gov.br

Brejão, G. L. (2012). Estradas, alagados antrópicos, peixes e a fragmentação de redes fluviais em uma paisagem agrícola do Nordeste do Pará. 2012. 97 f. Dissertação (Mestrado em Ciências Ambientais) Instituto de Geociências, Universidade Federal do Pará, Museu Paraense Emilio Göeldi, Empresa Brasileira de Pesquisa Agropecuária, Belém.

Bucci, M. M. H. S. et al. (2015). Análise de metais, agrotóxicos, parâmetros físico-quimicos e microbiológicos nas águas da represa Dr. João Penido, Juiz de Fora, MG. Revista Ambiente e Água, Taubaté, 10(4). https://doi.org/10.4136/ambi-agua. 1534

Bucci, M. M. H. S., \& Oliveira, L. F. C. (2014). Índices de qualidade da água e de estado trófico na represa Dr. João Penido (Juiz de Fora, MG). Revista Ambiente e Água, Taubaté, 9(1). https://doi.org/10.4136/ambi-agua.1290

Buck, O., Niyogi, D. K., \& Townsend, C. R. (2004). Scale-dependence of land use effects on water quality of streams in agricultural catchments. Environmental Pollution, 130(2), 287-299. https://doi.org/10.1016/j.envpol.2003.10.018

Bufon, A. G. M., \& Landim, P. M. B. (2007). Análise da qualidade da água por metodologia estatística multivariada na Represa Velha (CEPTA/IBAMA/Pirassununga/SP). HOLOS Environment, 7(1), 43. https://doi.org/10.14295/holos.v7i1.972 
Carneiro, C., \& Andreoli, C. V. (ed.). (2005). Gestão integrada de mananciais de abastecimento eutrofizados (p. 500). Curitiba: Sanepar; Finep.

Casquin, A. P. (2016). Fatores determinantes da qualidade da água na Bacia Hidrográfica do Rio Preto. Dissertação (Mestrado em Ecologia) - Instituto de Ciências Biológicas, Universidade Federal de Juiz de Fora, Juiz de Fora.

Cesama-Companhia De Saneamento Municipal. (2019). Mananciais. Represa Dr. João Penido. Juiz de Fora. Retrieved from http://www.cesama.com.br.

CETESB - Companhia de Tecnologia de Saneamento Ambiental. (2011). Guia Nacional De Coleta E Preservação De Amostras. CETESB - ANA, 2, 326.

CETESB - Companhia de Tecnologia de Saneamento Ambiental. (2016). Qualidade das águas doces do estado de São Paulo. Apêndice E - Significado Ambiental e Sanitário das Variáveis de Qualidade. São Paulo: CETESB.

Clément, F., Ruiz, J., Rodríguez, M. A., Blais, D., \& Campeau, S. (2017). Landscape diversity and forest edge density regulate stream water quality in agricultural catchments. Ecological Indicators, 72, 627-639. https://doi.org/10.1016/j.ecolind.2016.09.001

Forsyth, A. R., Bubb, K. A., \& Cox, M. E. (2006). Runoff, sediment loss and water quality from forest roads in a southeast Queensland coastal plain Pinus plantation. Forest Ecology and Management, 221(1-3), 194-206. https://doi.org/10.1016/j.foreco.2005.09.018

García-Montoya, M., Sengupta, D., Nápoles-Rivera, F., Ponce-Ortega, J. M., \& El-Halwagi, M. M. (2016). Environmental and economic analysis for the optimal reuse of water in a residential complex. Journal of Cleaner Production, 130, 82-91. https://doi.org/10.1016/j.jclepro.2015.06.109

Godwin, K. S., Hafner, S. D., \& Buff, M. F. (2003). Long-term trends in sodium and chloride in the Mohawk River, New York: The effect of fifty years of road-salt application. Environmental Pollution, 124(2), 273-281. https://doi.org/10.1016/S0269-7491(02)00481-5

$\mathrm{Gu}$, Q. et al. (2019). Characterizing the spatial variations of the relationship between land use and surface water quality using self-organizing map approach. Ecological Indicators, 102, 633-343. https://doi.org/10.1016/j.ecolind.2019.03.017

IBGE-Instituto Brasileiro De Geografia E Estatística. (2013). Manual técnico de uso da terra (3rd ed.). Rio de Janeiro: Instituto Brasileiro de Geografia e Estatística.

Jia, Z., Bian, J., \& Wang, Y. (2018). Impacts of urban land use on the spatial distribution of groundwater pollution, Harbin City, Northeast China. Journal of Contaminant Hydrology, 215(January), 29-38. https://doi.org/10.1016/j.jconhyd.2018.06.005

Juiz De Fora sempre. (2004). Plano Diretor de Desenvolvimento Urbano. FUNALFA Edições. Juiz de Fora.

Kändler, M., Blechinger, K., Seidler, C., Pavlů, V., Šanda, M., \& Dostál, T. (2017). Impact of land use on water quality in the upper Nisa catchment in the Czech Republic and in Germany. Science of the Total Environment, 586, 1316-1325. https://doi.org/10.1016/j.scitotenv.2016.10.221

Kisi, O., Alizamir, M., \& Docheshmeh Gorgij, A. R. (2020). Dissolved oxygen prediction using a new ensemble method. Environmental Science and Pollution Research, 27(9), 9589-9603. https://doi.org/10.1007/s11356-019-07574-w

Kuglerová, L., Ågren, A., Jansson, R., \& Laudon, H. (2014). Towards optimizing riparian buffer zones: Ecological and biogeochemical implications for forest management. Forest Ecology and Management, 334, 74-84. https://doi.org/10.1016/j.foreco.2014.08.033

Lana, J. N. de. (2020). Correlacionando a qualidade da água com o uso e a cobertura da terra: um estudo da Bacia de Contribuição da Represa Doutor João Penido, Juiz de For a (MG). Dissertação (Mestrado em Ambiente Construído) - Faculdade de Engenharia, Universidade Federal de Juiz de Fora, Juiz de Fora.

López-Doval, J. C., Montagner, C. C., de Alburquerque, A. F., Moschini-Carlos, V., Umbuzeiro, G., \& Pompêo, M. (2017). Nutrients, emerging pollutants and pesticides in a tropical urban reservoir: Spatial distributions and risk assessment. Science of the Total Environment, 575, 1307-1324. https://doi.org/10.1016/j.scitotenv.2016.09.210

Machado, P. J. O. (2012). Diagnóstico ambiental e ordenamento territorial - instrumentos para a gestão da 
Bacia de Contribuição da Represa de Chapéu D'ùvas/MG. Tese (Doutorado em Geografia) - Faculdade de Geografia, Universidade Federal Fluminense, Niterói.

Mehdi, B., Lehner, B., Gombault, C., Michaud, A., Beaudin, I., Sottile, M. F., \& Blondlot, A. (2015). Simulated impacts of climate change and agricultural land use change on surface water quality with and without adaptation management strategies. Agriculture, Ecosystems and Environment, 213, 47-60. https://doi.org/10.1016/j.agee.2015.07.019

Mello, K. de, Valente, R. A., Randhir, T. O., dos Santos, A. C. A., \& Vettorazzi, C. A. (2018). Effects of land use and land cover on water quality of low-order streams in Southeastern Brazil: Watershed versus riparian zone. Catena, 167(April), 130-138. https://doi.org/10.1016/j.catena.2018.04.027

Menezes, J. P. C., Bertossi, A. P. A., Santos, A. R., \& Neves, M. A. (2014). Correlação entre uso da terra e qualidade da água subterranean. Engenharia Sanitaria e Ambiental, 19(2), 173-186. https://doi.org/10.1590/S1413-41522014000200008

Moschet, C., Wittmer, I., Simovic, J., Junghans, M., Piazzoli, A., \& Singer, H. (2014). How a complete pesticide screening changes the assessment of surface water quality. Environmental Science and Technology, 48(10), 5423-5432. https://doi.org/10.1021/es500371t

Nguyen, H. H., Recknagel, F., Meyer, W., Frizenschaf, J., \& Shrestha, M. K. (2017). Modelling the impacts of altered management practices, land use and climate changes on the water quality of the Millbrook catchment-reservoir system in South Australia. Journal of Environmental Management, 202, 1-11. https://doi.org/10.1016/j.jenvman.2017.07.014

Nilsson, C., \& Berggren, K. (2000). Alterations of riparian ecosystems caused by river regulation. BioScience, 50(9), 783-792. https://doi.org/10.1641/0006-3568(2000)050[0783:AORECB]2.0.CO;2

Nobre, R. L. G., Caliman, A., Cabral, C. R., Araújo, F. de C., Guérin, J., \& Dantas, F. da C. C. (2020). Precipitation, landscape properties and land use interactively affect water quality of tropical freshwaters. Science of the Total Environment, 716, 137044. https://doi.org/10.1016/j.scitotenv.2020.137044

Nunes, S., Barlow, J., Gardner, T., Sales, M., Monteiro, D., \& Souza, C. (2019). Uncertainties in assessing the extent and legal compliance status of riparian forests in the eastern Brazilian Amazon. Land Use Policy, 82(April 2018), 37-47. https://doi.org/10.1016/j.landusepol.2018.11.051

Oliveira, M. (2018). Limnologia da Paisagem com uso de Regressão Geograficamente Ponderada: estudo da qualidade da água na represa de Chapéu D'Úvas, MG. Tese (Doutorado em Ecologia) - Instituto de Ciências Biológicas, Universidade Federal de Juiz de Fora, Juiz de For a.

Oliver, S., Corburn, J., \& Ribeiro, H. (2019). Challenges regarding water quality of eutrophic reservoirs in urban landscapes: A mapping literature review. International Journal of Environmental Research and Public Health, 16(1). https://doi.org/10.3390/ijerph16010040

Palma, P., Köck-Schulmeyer, M., Alvarenga, P., Ledo, L., Barbosa, I. R., López de Alda, M., \& Barceló, D. (2014). Risk assessment of pesticides detected in surface water of the Alqueva reservoir (Guadiana basin, southern of Portugal). Science of the Total Environment, 488-489(1), 208-219. https://doi.org/10.1016/j.scitotenv.2014.04.088

Pandey, A., Himanshu, S. K., Mishra, S. K., \& Singh, V. P. (2016). Physically based soil erosion and sediment yield models revisited. Catena, 147, 595-620. https://doi.org/10.1016/j.catena.2016.08.002

Peña-Arancibia, J. L., Bruijnzeel, L. A., Mulligan, M., \& van Dijk, A. I. J. M. (2019). Forests as 'sponges' and 'pumps': Assessing the impact of deforestation on dry-season flows across the tropics. Journal of Hydrology, 574(April), 946-963. https://doi.org/10.1016/j.jhydrol.2019.04.064

Pereira, M. J. A. (1991). Estudos limnológicos preliminares da represa Dr. João Penido - Juiz de Fora - MG. 1991. Monografia (pós-graduação latu sensu em Ecologia e Manejo de Águas Interiores). Universidade de São Carlos. São Carlos.

Pickett, S. T. A., Cadenasso, M. L., Grove, J. M., Boone, C. G., Groffman, P. M., \& Irwin, E. (2011). Urban ecological systems: Scientific foundations and a decade of progress. Journal of Environmental Management, 92(3), 331-362. https://doi.org/10.1016/j.jenvman.2010.08.022

Pocewicz, A., \& Garcia, E. (2016). Deforestation facilitates widespread stream habitat and flow alteration in the Brazilian Amazon. Biological Conservation, 203, 252-259. https://doi.org/10.1016/j.biocon.2016.09.032

Pringle, C. M. (2006). Hydrologic connectivity: A neglected dimension of conservation biology. In K. Crooks \& 
M. Sanjayan (Eds.), Connectivity conservation (pp. 233-254). New York: Cambridge University Press. https://doi.org/10.1017/CBO9780511754821.011

Rabelo, C. G., Ferreira, M. E., Araújo, J. V. G., Stone, L. F., Silva, S. C., \& Gomes, M. P. (2009). Influência do uso na qualidade da água no bioma Cerrado: um estudo comparativo entre bacias hidrográficas no estado de Goiás, Brasil. Revista Ambiente e Água, 4(2), 172-187. https://doi.org/10.4136/ambi-agua.96

Rebouças, A. da C., Braga, B., \& Tundisi, J. G. (2006). Águas doces no Brasil - capital ecológico, uso e conservação (3rd ed., p. 748). São Paulo: Editora Escrituras.

Ribeiro, C. R. (2012). Planejamento ambiental e gestão de recursos hídricos na bacia hidrográfica da Represa de Chapéu D'úvas - zona da mata e campo das vertentes/MG. Dissertação (Mestrado em Geografia) Faculdade de Ciências e Tecnologia. Universidade Estadual Paulista, Presidente Prudente.

Rocha, A. A., \& Branco, S. M. (1986). Proposições básicas para a proteção ambiental da represa Dr. João Penido em Juiz de Fora, MG. São Paulo.

Rocha, C. H., Casquin, A. P., \& Pereira, R. O. (2019a). Correlations chart: Tool to analyse the dynamics of water quality parameters. Revista Brasileira de Engenharia Agrícola e Ambiental, 23(5), 383-390. https://doi.org/10.1590/1807-1929/agriambi.v23n5p383-390

Rocha, C. H. B., Casquin, A. P., Silva, T. M., Freitas, F. A., Pereira, A., Paula, I. F. M., \& Almeida Neto, J. O. (2020). Dinâmica de parâmetros limnológicos e uso e cobertura da terra nas bacias hidrográficas das represas Dr. João Penido e São Pedro, Juiz de Fora (MG). Principia: Caminhos da Iniciação Científica, 18(1), 11. https://doi.org/10.34019/2179-3700.2018.v18.29840

Rocha, C. H. B., Freitas, F. A. de, \& Casquin, A. P. (2019b). Conflitos de uso da terra nas APPs hídricas de manancial da Zona da Mata Mineira, Brasil. Boletim Goiano de Geografia, 39, 1-22. https://doi.org/10.5216/bgg.v39i0.50021

Rocha, C. H. B., Freitas, F. A., \& Silva, T. M. da. (2014). Alterações em variáveis limnológicas de manancial de Juiz de Fora devido ao uso da terra. Revista Brasileira de Engenharia Agrícola e Ambiental, 18(4), 431-436. https://doi.org/10.1590/s1415-43662014000400011

Rocha, C. H. B., \& Pereira, A. M. (2016). Análise multivariada para seleção de parâmetros de monitoramento em manancial de Juiz de Fora, Minas Gerais. Revista Ambiente e Água, Taubaté, 11(1). https://doi.org/10.4136/ambi-agua.1590

Rodrigues, V., Estrany, J., Ranzini, M., de Cicco, V., Martín-Benito, J. M. T., Hedo, J., \& Lucas-Borja, M. E. (2018). Effects of land use and seasonality on stream water quality in a small tropical catchment: The headwater of Córrego Água Limpa, São Paulo (Brazil). Science of the Total Environment, 622-623, 1553-1561. https://doi.org/10.1016/j.scitotenv.2017.10.028

Rong, Y. (2011). Practical environmental statistics and data analysis (p. 269). Glendale: ILM Publications.

Sabino, C. V. S., Lage, L. V., \& Noronha, C. V. (2017). Variação sazonal e temporal da qualidade das águas em um ponto do Córrego Gameleiras usando técnicas quimiométricas robustas. Eng Sanit Ambiental, 22(5), 969-983. https://doi.org/10.1590/s1413-41522017158455

Santos, R. M. B., Sanches Fernandes, L. F., Cortes, R. M. V., Varandas, S. G. P., Jesus, J. J. B., \& Pacheco, F. A. L. (2017). Integrative assessment of river damming impacts on aquatic fauna in a Portuguese reservoir. Science of the Total Environment, 601-602, 1108-1118. https://doi.org/10.1016/j.scitotenv.2017.05.255

Shi, P., Zhang, Y., Li, Z., Li, P., \& Xu, G. (2017). Influence of land use and land cover patterns on seasonal water quality at multi-spatial scales. Catena, 151, 182-190. https://doi.org/10.1016/j.catena.2016.12.017

Silva, K. C. Da, \& Poleto, C. (2017). Drenagem Urbana Sustentável: Aspectos Hidrológicos, Influência dos Sedimentos e o Reequilibrio dos Ciclos Naturais. II Congresso Internacional de Hidrossedimentologia, Anais, $6 . \quad$ Retrieved from https://www.lume.ufrgs.br/bitstream/handle/10183/170574/001025262.pdf?sequence=1

Straškraba, M., \& Tundisi, J. G. (2013). Gerenciamento da Qualidade da água de Represas (v. 9. Diretrizes para o gerenciamento de lagos, 3rd ed.). São Paulo: Oficina de Textos.

Taniwaki, R. H., Cassiano, C. C., Filoso, S., Ferraz, S. F. de B., Camargo, P. B. de, \& Martinelli, L. A. (2017). Impacts of converting low-intensity pastureland to high-intensity bioenergy cropland on the water quality of tropical streams in Brazil. Science of the Total Environment, 584-585, 339-347. https://doi.org/10.1016/j.scitotenv.2016.12.150 
Tasdighi, A., Arabi, M., \& Osmond, D. L. (2017). The Relationship between Land Use and Vulnerability to Nitrogen and Phosphorus Pollution in an Urban Watershed. Journal of Environmental Quality, 46(1), 113-122. https://doi.org/10.2134/jeq2016.06.0239

Tundisi, J. G. (2018). Reservoirs: New challenges for ecosystem studies and environmental management. Water Security, 4-5(May), 1-7. https://doi.org/10.1016/j.wasec.2018.09.001

Valente, J. P. S., Padilha, P. M., \& Silva, A. M. M. (1997). Oxigênio dissolvido (OD), demanda bioquímica de oxigênio (DBO) e demanda química de oxigênio (DQO) como parâmetros de poluição no ribeirão Lavapés/Botucatu - SP. Eclética Química, São Paulo, 22, 49-66. https://doi.org/10.1590/S0100-46701997000100005

Vanzela, L. S., Hernandez, F. B. T., \& Franco, R. A. M. (2010). Influência do uso e ocupação do solo nos recursos hídricos. Revista Brasileira de Engenharia Agrícola e Ambiental, 14(17), 55-64. https://doi.org/10.1590/S1415-43662010000100008

Wang, X., \& Yin, Z. Y. (1997). Using GIS to assess the relationship between land use and water quality at a $\begin{array}{lllll}\text { watershed level. Environment } & \text { International, }\end{array}$ https://doi.org/10.1016/S0160-4120(96)00081-5

White, P., Ruble, C. L., \& Lane, M. E. (2013). The effect of changes in land use on nitrate concentration in water supply wells in southern Chester County, Pennsylvania. Environmental Monitoring and Assessment, 185(1), 643-651. https://doi.org/10.1007/s10661-012-2581-5

WHO. (2016). Quantitative Microbial Risk Assessment: Application for Water Safety Management (p. 187). WHO Press. http://www.who.

\section{Copyrights}

Copyright for this article is retained by the author, with first publication rights granted to the journal.

This is an open-access article distributed under the terms and conditions of the Creative Commons Attribution license (http://creativecommons.org/licenses/by/4.0/). 